\title{
NOTES AND REVIEWS
}

\section{SMALL BOATS FOR USE IN SPITSBERGEN}

[Based on a note provided by P. S. B. Digby.]

The coast of Spitsbergen consists predominantly of sand or gravel beaches, without creeks or inlets. The most suitable boats for use in coastal waters therefore fall into two main divisions: those over $25 \mathrm{ft}$. in length, which can ride at anchor in rough weather, and those under $25 \mathrm{ft}$. which can easily be hauled up the beach. The latter types of craft form the subject of this note.

A $16 \mathrm{ft}$. Strandelbarmar rowboat can be both handled and hauled up the beach by two people. These boats have a pointed bow and stern, are very seaworthy, and can ride out summer squalls. They can be fitted with a light outboard motor, e.g. a "Seagull", and will then make a steady 4 knots, laden or light; $200 \mathrm{lb}$. of gear can be carried comfortably, and larger loads for short distances. These boats are made in Bergen.

The Ordver boats (from Or, just south of Bergen) have a good local reputation, but as the bow and stern are more flared they do not appear suitable for use with outboard motors.

The inhabitants of Spitsbergen favour a larger craft, some $18 \mathrm{ft}$. in length, with a transom stern and a heavy outboard engine, e.g. "Eivenrudes", Johnson."Sea-horse". Two people cannot easily haul these craft up the beach, and for this reason they are usually manned by a crew of three or four. They are no more seaworthy than the Strandelbarmar.

Norsk Polarinstitutt favours heavy, flat-bottomed dories, approximately $18 \mathrm{ft}$. long. These resemble landing-craft and can run inshore and ground on the whole width of their bottom, so that gear can be landed quickly and efficiently. They may be very heavily laden, but require a powerful outboard engine, e.g. a Swedish 8 h.p. "Penta". A block-and-tackle is required to haul these craft above the high-water mark, and they are difficult to row in case of engine trouble. They normally require a crew of three persons. From the point of view of landing equipment these boats are incomparably the best, but they are unsatisfactory in open water in rough weather.

In 1948 P. S. B. Digby found that marine biological work (hauling plankton nets) in Adventfjorden and other parts of Isfjorden could be undertaken in a Strandelbarmar during the whole of June, most of July and about two-thirds of August; after this the.weather begins to break, in early September. In mid-summer it is nearly always possible to avoid the wind by travelling at night. 